\title{
Matching Teams to Business Processes
}

\author{
Nikita Byer, and Richard H. Weston \\ MSI Research Institute, Loughborough University, United Kingdom, r.h.weston@lboro.ac.uk
}

\begin{abstract}
Progress has been towards developing 'reference models of human teams'. A classification is made based upon the purpose of teams by accounting for observed differences in 'structure' and 'composition' properties of teams described in the human factors literature. A reusable understanding of these characteristic properties should (1) inform the 'initial design and formulation of enterprise teams', and thereby match the composition and structure of teams to specified business processing needs and (2) help focus 'continuing task development carried out by teams' through their useful lifetime.
\end{abstract}

\section{TEAMWORKING - BENEFITS AND PROBLEMS}

Although industry at large is deploying many types of team a number of problems have emerged (Anantharaman, et al, 1984). Recent reports indicate that $70 \%$ of teams fail to produce desired results (Tranfield, et al, 1998). Improperly applied team working can increase lead-times needed to complete tasks. The empowerment of individuals and work teams can generate highpressure environments with low slack and little buffering. A darker side of team working and empowerment can be strong group norms and powerful individuals stifling individual flair and self-expression (Barker, 1993). A connected downside is the lack of visibility of the individual working of teams, particularly in complex environments where multiple team solutions are needed and hence effective inter-team integration is a requirement.

Certainly with respect to specific instances of enterprise need, it is unclear as to whether or not team working constitutes a more efficient organisation of social system resources when compared to more traditional organisational forms used by industry. Also necessary prior to any completion of team tasks: (1) 'team design requirements' must be specified

\footnotetext{
The original version of this chapter was revised: The copyright line was incorrect. This has been
} corrected. The Erratum to this chapter is available at DOI: 10.1007/978-0-387-35621-1_43 
team tasks: (1) 'team design requirements' must be specified (e.g. the 'composition' and 'structure' of teams and the 'responsibilities' of team members must be determined) and (2) activities needed to satisfactorily realise task completion require formulation and planning.

The longer it takes to design and operationalise a team the longer it will take the team to complete its first task. But the quality of the team design will directly influence the quality with which tasks are completed. Hence matters of team design can be very important and should not be trivialised.

\section{STATIC AND DYNAMIC ASPECTS OF TEAMS}

Seminal work of Syer and Connolly (1996) considers teams to be systems. Some elements of any team system causally and temporally link processes realised by the team or processes that transform a team. Generally this leads to circular cause and effect relationships that over time effect dynamic behaviours of the team. Inputs to the team system are transformed to outputs via team processes in accordance with team structures. Syer and Connolly (1996) considered the structure of a team to comprise those relatively static and enduring aspects, while its processes concern patterns in the team's system behaviour in response to relatively dynamic or transient factors by virtue of change or instability. Syer's team structures include specifications for the size of a team, team membership, a place and time to meet, team roles and team goals and objectives. Team processes will be norms that include methods of problem solving, decision-making and planning. The team system acts to transform inputs to outputs through its processes. Once established processes are subject to deviation from target values and because of internal and external factors produce 'error states'. Team processes can be defined in terms of sets of temporarily ordered activities that consume resources available to the team so as to transform ideas, skills and qualities of team members, materials, problems, etc into discoveries, solutions, proposals, actions, design ideas and products. These input-output transformations are subject to speaking skills, agendas, time management, descriptive feedback, warming up and task methodology.

Smith (1987) refers to team structures as frozen processes. This helps explain the notion that teams have an inherent capability to evolve their behaviours by freezing and unfreezing processes so as to change team structures. This differentiates capabilities of relatively simple groups of technical resources from teams of people although advances in software agent technologies have begun to blur this differentiation. Hardingham (1994) points to common features of all teams even when they function differently. She identified four stages of the 'Team Life Cycle', namely: Forming Stage: the team is under-developed and its members are concerned with who fits 
is under-developed and its members are concerned with who fits where; Storming Stage: the team is experimenting and concerned with how members can work together; Performing Stage: the team is mature and concerned with goal achievement; Mourning Stage: the team is ending and concerned with breaking up and moving on to new tasks.

Also referring to the lifetime of teams, Foster et al (1996) explained that some teams perform a function then disband after original goals are achieved. But this may not be the case where reoccurring tasks need to be performed, or where new tasks arise of similar type. Hence the same team may be reused. Implicated within the models of teams of Syer and Connolly (1996), Smith (1987), Hardingham (1994), Foster (1996) and Larson and LaFasto (1989) is that structure can be determined in two (possibly complementary) ways, viz.: (i) identify candidate team compositions and structures needed for the achievement of specific objectives (i.e. to adopt a top-down approach to team design and change); (ii) identify candidate team compositions and structures that best co-ordinate the competences of team members (i.e. to engineer and develop teams in a bottom-up manner).

In many practical cases it is assumed that the 'design' and 'development' of teams needs to be ongoing.

\section{LIFE-CYCLE ENGINEERING OF TEAMS - MATCHING TEAMS TO BP'S}

At the MSI Research Institute in the UK a research programme is underway which seeks to deploy enterprise modelling (EM) and enterprise integration (EI) technologies in support of the life cycle of enterprise teams. The programme comprises a number of projects with joint support from the UK's EPSRC and a consortium of manufacturing businesses. Individual projects are focused on different life-cycle aspects and seek to evaluate developed EM \& EI methods for use in different industrial domains. The aim is to use both static and dynamic team models (in visual, tabular and computer executable forms) to structure key aspects of ongoing team-based engineering. This should not 'handcuff teams' but rather improve their initial and integrated design and as appropriate inform their ongoing development so that (a) best practice can be transferred, (b) capital value can be placed on teams and (c) teams design and operation can remain effective within various complex and changing business environments.

Collectively the projects cover the following phases of team engineering: 'specification of team requirements'; 'team design'; 'team implementation'; 'team development'; 'task development' and 'team maintenance'. 
A common feature of the projects is their focus on matching (1) static and dynamic competences of teams to (2) goals and task requirements, identified in terms of business process models. It has been assumed that such a focus can: lead both to intra and inter organisational design of teams; facilitate ongoing team engineering; enable business benefit and analysis with respect to team-based strategy and policy making. This assumption is being tested by the industrial evaluation work. The remainder of this paper is focused on results from one of the projects that has developed a static reference model of teams to inform decision-making during 'team design'.

DEVELOPING A NEW TEAM CLASSIFICATION

\subsection{Initial Literature Review}

In 2001, the authors conducted a literature review of 'team types' listed in Table 1. The study found limits on the reuse of human factors knowledge which stem from (1) significant overlap in the scope and purpose of alternative team descriptions, (2) inconsistent use of terminology and (3) varying levels of abstraction at which properties of teams are analysed.

Table 1: Names of teams attributed by the literature

\begin{tabular}{|lll|}
\hline - Steering Teams & - Tiger Teams & - Virtual Teams \\
- Planning Teams & - Launch Teams & - Top-Management Ts \\
- Proc. Improvement & - Work Teams & - Mid-Management Ts \\
Ts & - Project Teams & - Ad Hoc Teams \\
- Self Managed Teams & - Focus Teams & - Work Groups \\
- Multi-disciplinary Ts & - Task Force & - Quality Circles \\
- Interdisciplinary Ts & - Natural Groups & - Co-ordination Teams \\
- Impact Teams & - Functional Teams & - Think Tank Teams \\
- Cross Functional Ts & & \\
\hline
\end{tabular}

In Loughborough (http://) the authors draw tabulated comparisons between the team types described in the literature with respect to their 'main purpose', 'make-up', information flows', 'focus', 'behaviour', 'leadership', 'degree of autonomy', 'membership time-span' and 'team limitations'.

\subsection{Primary Team Selection Actors and Activities}

Any enterprise team selection process will involve 'choosing a team with competences to perform a defined set of activities within an acceptable time 
frame, in order to deliver specified outputs'. But it was observed that no formal method of team selection is reported in the literature. Current best industry practice observed by the authors at collaborator sites is as follows: (i) The team already exists in the organisation and after fulfilling a role with respect to an initial task set it is assigned alternative responsibility for a new task set; (ii) A group of individuals are formed into a team without a welldefined structure or process and it is assumed that a suitable structure and process will emerge over time.

Therefore current enterprise team selection is ad hoc and incompletely planned. Normally though complementary team roles, processes and structures develop over a period of time after tenure trial and error. During forming and storming stages process lead-times and efficiencies will be degraded. It follows that the initial selection of a team can have a major influence on the team's performance, its outputs and the time it takes to perform acceptably. The more suited the initial team design is to performing assigned tasks the sooner it can carry them out satisfactorily (on a continuing basis if required).

It was observed that the performance of any new team selection method must suit the needs of would-be 'customers'. In this respect two main customer groups were considered, namely 'team initiators' and 'team designers'. It was assumed that the team initiator customer group would likely operate mainly with a strategic or tactical purpose, with respect to the design or development of one or more business processes. Team designers were expected to use information (about process definitions and outline resource requirements) generated by team initiators and to couple this to knowledge about suitable teams in order to select a viable team type. It was also understood that teams specified and selected by team initiators and team designers might be required to operate for strategic, tactical or operational purposes.

\subsection{Knowledge Needed-Enterprise Modelling Views}

The study considered general requirements of 'team initiator' and 'team designer' customers. This consideration was cognisant of reported deficiencies of current ad hoc team selection practice used by collaborating companies.

Fig. 1 illustrates the general context of the team selection process. The team initiator's role is to identify a need for teams and, associated with this, develop outline requirements definitions and human resourcing policies. This might typically include some form of general task definition. The role of team designers is to determine the composition, structure and other properties of teams. Typically they might detail team objectives, develop descriptions of one or more viable teams and conduct an analysis to differentiate 
between candidate teams, e.g. in terms of their performance, cost and quality of outputs, 'flexibility', etc. Based on this line of thinking it was observed that common classes of information needed to facilitate team selection include: 'team function'; 'team leadership styles'; 'team size'; 'team composition'; 'team organisation'; 'team resource'; and 'team activities'.

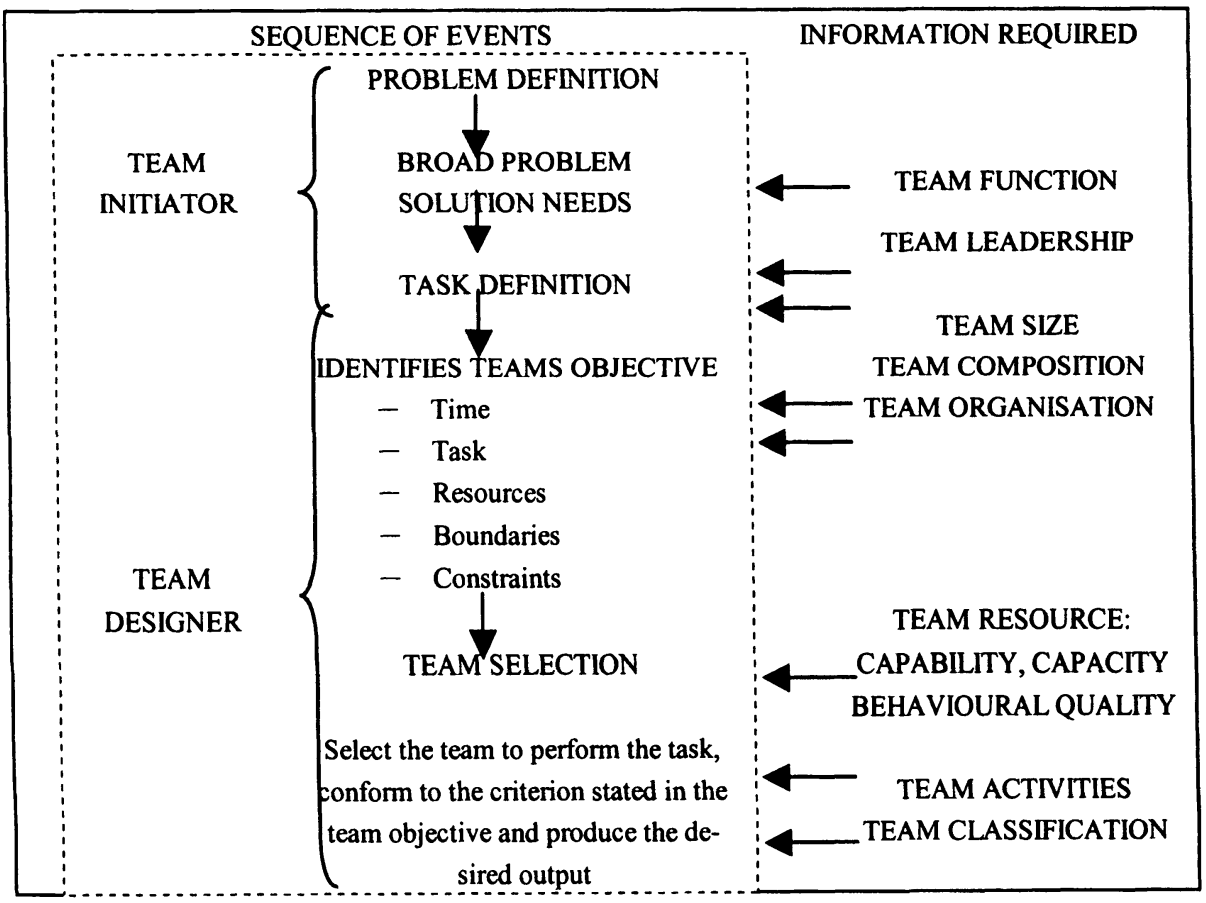

Figure 1: Typical events that impact on team selection

\subsection{Analysis of Team Classifications by Purpose}

Previous authors had developed team classifications with reference to their purpose. One such classification (Moris, et al, 2000) distinguishes between Integrated Product Development (IPD) teams currently deployed in aerospace industries. Three main classes of team were observed, so called 'management', 'core' and 'task' teams. Differentiation between team classes was made based on the following views: 'team focus'; 'team composition'; 'team purpose or responsibility'; 'team skill base'; and 'team controls'. However, an observed critical limitation of this and other previous classifica- 
cations of teams by purpose is that information about 'team objective' and 'leadership style' is not adequately represented.

\subsection{A New and Enhanced Team Classification}

A new and enhanced classification of teams was developed with respect to their 'purpose'. Cognisance was taken of the three main classes of enterprise activities (BS ISO 14258, 1998), namely: (i) Strategic Teams: that 'run things' and are responsible for WHAT enterprise activities; (ii) Tactical Teams: that 'recommend things' being responsible for HOW enterprise activities; (iii) Operational Teams: that 'make or DO things'.

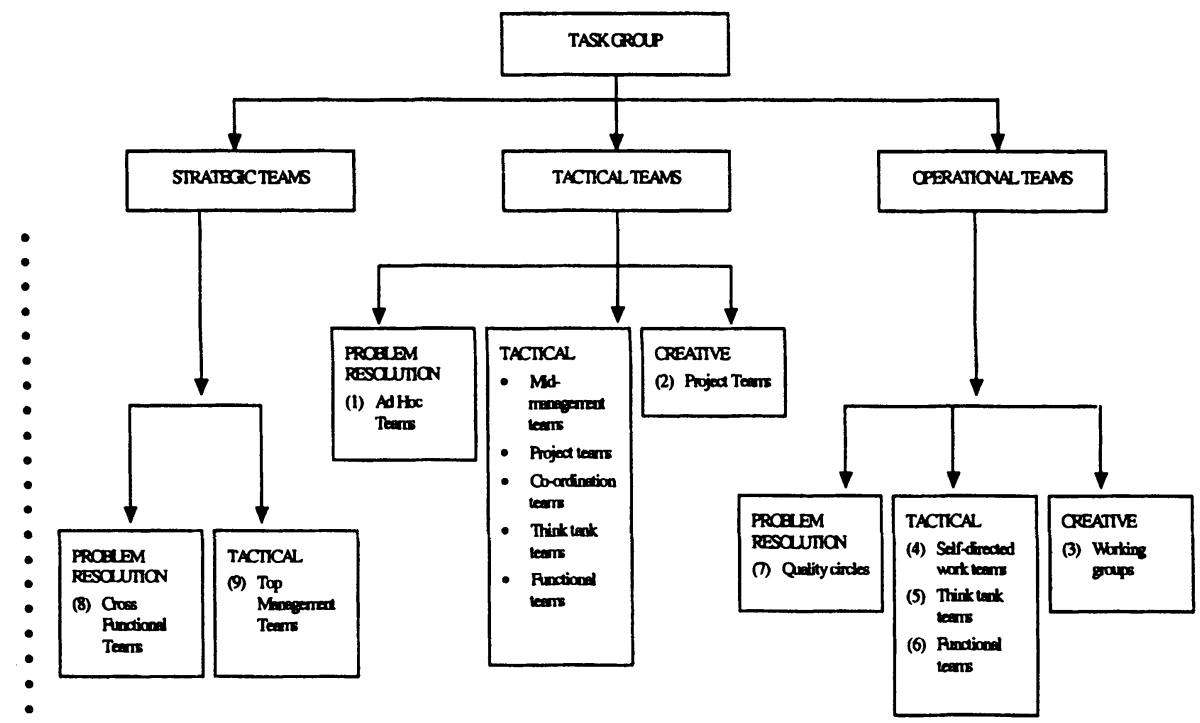

Figure 2: Team Classification Chart

Table 2 lists five broad groupings of questions that require answers during the team selection process. Answers to these questions were analysed for teams classified under (i) through (iii), in terms of (a) achieving team goals and (b) determining obstacles and opportunities associated with teamwork. This analysis helped clarify distinctions drawn between teams and led to the development of Tables 3, 4 and 5 which constitutes a new reference model of enterprise teams with respect to their purpose. Results from the analysis were also used to construct the team classification chart shown in Fig. 2. 
Table 2: Criterion for Team Selection

Team Function - Why should this team type be formed?

What does it do? What is the overall purpose?

What are the critical success factors? What are the priorities?

What external information does the team need?

What type (size and generality) of problem does the team solve?

Team Performance - How is the team performance measured?

How well does the team achieve its objectives?

What time constraints exist on achieving objectives?

What makes the team productive?

What kind of relationship is there between team members? What kind of relationship is necessary for achieving goals?

Are the goals and objectives clearly defined? Must the team be flexible?

Competition - Whom, if anyone, is the team meant to beat?

Will the team be competing against other teams?

Are competing teams inside or outside that organisation?

What are the benefits of competition? What are the disadvantages?

Team Roles - Are the roles clearly defined in the team?

Can team roles be swapped between team members?

Could team members fulfil any of the roles, or are there many 'specialist' roles?

To what extent do the interactions; information exchange and joint working of team members need to be orderly, predictable and polished? Is the team structure formal or informal? Are there defined paths for information and data flow?

Team Relationships - What are the relationships between team members?

How important is loyalty to the team? What are the disadvantages of loyalty?

Is the team size and membership fixed or predetermined? Do team members belong to more than one team, and is that necessary?

Will the team have part-time members? What is the length of the team life cycle?

What are the advantages of people staying in a team for a long time? What are the disadvantages?

Table 3: Recognisable strategic team needs and requirements

\begin{tabular}{|c|l|}
\hline Items & \multicolumn{1}{c|}{ Needs } \\
\hline Team & Teams that run things, management teams. \\
& $-\quad$ Sets company direction, determines organisation's mission, goals, objec- \\
& tives and priorities \\
- & Serves as the major link between the organisation and the outside world \\
$-\quad$ Creates organisational plans and strategies based on information from the \\
& $\begin{array}{l}\text { internal and external environment: competitors, market demand, internal } \\
\text { capabilities }\end{array}$ \\
& $\begin{array}{l}\text { Problem types are generally wide ranging and generally deal with situa- } \\
\text { tions that arise external to the organisation }\end{array}$ \\
\hline
\end{tabular}


Table 3: (continued) Recognisable strategic team needs and requirements

\begin{tabular}{|c|c|}
\hline $\begin{array}{l}\text { Team } \\
\text { Perform- } \\
\text { ance }\end{array}$ & $\begin{array}{l}\text { - Team generally sets short, medium and long term goals or objectives } \\
\text { - Objectives are measurable and generally include increase in ROI, in- } \\
\text { creased market share, training of staff, penetration of new markets } \\
\text { - The teams performance is determined by the achievement of goals set, } \\
\text { these goals are clearly measurable. }\end{array}$ \\
\hline $\begin{array}{l}\text { Competi- } \\
\text { tion }\end{array}$ & $\begin{array}{l}\text { This team-type sets plans and strategies that will enable their company to } \\
\text { compete in any world market. They are competing against similar teams in } \\
\text { many organisations around the world } \\
\text { Advantage of Competition: to increase the organisational standards and allow } \\
\text { the company to compete in the international arena. Disadvantage: In an at- } \\
\text { tempt to compete organisations may take on more than they can handle. }\end{array}$ \\
\hline $\begin{array}{l}\text { Team } \\
\text { Members } \\
\text { Roles }\end{array}$ & $\begin{array}{l}\text { Generally cross-functional teams that span all aspects of the organisation. } \\
\text { Team member's roles are well defined and the team consists of a large num- } \\
\text { ber of specialists. } \\
\text { The team structure is formal and somewhat hierarchical. }\end{array}$ \\
\hline $\begin{array}{l}\text { Relation- } \\
\text { ships }\end{array}$ & $\begin{array}{l}\text { Important relationship factors: } \\
\text { - Team size and membership are generally fixed } \\
\text { - Team loyalty is important } \\
\text { - Team members usually belong to more than one team } \\
\text { - The team may also use consultants or specialists } \\
-\quad \text { Long team lifecycle }\end{array}$ \\
\hline $\begin{array}{l}\text { Team } \\
\text { Leader- } \\
\text { ship }\end{array}$ & $\begin{array}{l}\text { Delegating style of leadership where leaders respond to proposals and sug- } \\
\text { gestions from the team. The team consists of competent experienced mem- } \\
\text { bers. } \\
\text { This team type is also characterised by an inspirational / charismatic style of } \\
\text { leadership. This type of leadership exists in high-risk situations where the } \\
\text { teams are highly competent. }\end{array}$ \\
\hline $\begin{array}{l}\text { Team } \\
\text { Types }\end{array}$ & $\begin{array}{l}-\quad \text { Top management teams } \\
-\quad \text { Cross-functional teams }\end{array}$ \\
\hline $\begin{array}{l}\text { Typical } \\
\text { Team } \\
\text { Structures }\end{array}$ & $\begin{array}{l}\text { - Problem resolution } \\
\text { - Tactical }\end{array}$ \\
\hline
\end{tabular}

Table 4: Recognisable tactical team needs and requirements

\begin{tabular}{|c|l|}
\hline Items & \multicolumn{1}{c|}{ Needs } \\
\hline Team & Teams that recommend things, core teams \\
& $-\quad$ Develops clear objectives and controls and co-ordinates work throughout \\
the organisation & $-\quad$ New product development manufacturing processes, new marketing \\
& strategies, cost reduction ideas, new business ventures \\
$-\quad$ Product decomposition and product integration & $-\begin{array}{l}\text { Develop the day-to-day plans of action that support the strategies and } \\
\text { objectives set by the strategic team }\end{array}$ \\
& $\begin{array}{l}\text { Problems are wide ranging but cover issues that are within the organisa- } \\
\text { tion }\end{array}$ \\
\hline
\end{tabular}


Table 4: (continued) Recognisable tactical team needs and requirements

\begin{tabular}{|c|c|}
\hline $\begin{array}{l}\text { Team } \\
\text { Perform- } \\
\text { ance }\end{array}$ & $\begin{array}{l}\text { - Teams objectives are generally project, process or product oriented } \\
\text { - Team generally sets short, medium and long term goals or objectives, } \\
\text { based } \mathrm{n} \text { the constraints which are determined by the strategic teams } \\
\text { - Team productivity is measured by the rate at which the desired goal is } \\
\text { achieved. Objectives include: new product design, project management. }\end{array}$ \\
\hline $\begin{array}{l}\text { Competi- } \\
\text { tion }\end{array}$ & $\begin{array}{l}\text { These teams would not necessarily be competing against other teams but } \\
\text { rather against constraints imposed on them by the strategic teams. These } \\
\text { constraints include monetary, time, resources constraints. The constraints set } \\
\text { by the strategic team would ensure that the tactical team accomplished the } \\
\text { desired task in the given time with the resources available to ensure that the } \\
\text { organisation remains internationally competitive. }\end{array}$ \\
\hline $\begin{array}{c}\text { Team } \\
\text { Members } \\
\text { Roles }\end{array}$ & $\begin{array}{l}\text { These teams can be both cross-functional and functional. In functional teams } \\
\text { the members can be rotated. } \\
\text { Depending on the nature of the task to be performed the team structure can } \\
\text { be formal or informal. For example, if the team's objective is project man- } \\
\text { ager, then the structure is formal and somewhat hierarchical. However, if the } \\
\text { team's objective is new product development then team creativity is essential } \\
\text { and the team structure is flat and informal. }\end{array}$ \\
\hline $\begin{array}{l}\text { Relation- } \\
\text { ships }\end{array}$ & $\begin{array}{l}\text { Important relationship factors: } \\
\text { - Team size and membership is determined by the team's task } \\
\text { - Teams can be functional or cross-functional in nature. } \\
\text { - Team's life cycle is determined by the nature of the task. It should be } \\
\text { noted that these teams are generally transferred from one task to another } \\
\text { and generally have long life cycles. }\end{array}$ \\
\hline $\begin{array}{l}\text { Team } \\
\text { Leader- } \\
\text { ship }\end{array}$ & $\begin{array}{l}\text { There are two types of team leadership styles that are characteristic of these } \\
\text { types of teams: } \\
\text { - Directive - teams at initiation, members unsure of tasks, leaders give } \\
\text { information and direction } \\
\text { - Delegating - teams competent and experienced, leaders respond to } \\
\text { proposals and suggestions from members. }\end{array}$ \\
\hline $\begin{array}{l}\text { Team } \\
\text { Types }\end{array}$ & $\begin{array}{l}\text { - Ad hoc teams } \\
\text { - Mid-management teams } \\
\text { - Project teams } \\
\text { - Co-ordination teams } \\
\text { - Think tank teams } \\
\text { - Functional and cross-functional teams }\end{array}$ \\
\hline $\begin{array}{c}\text { Typical } \\
\text { Team } \\
\text { Structures }\end{array}$ & $\begin{array}{l}\text { - Problem resolution } \\
-\quad \text { Tactical } \\
- \text { Creative }\end{array}$ \\
\hline
\end{tabular}


Table 5: Recognisable operational team needs and requirements

\begin{tabular}{|c|c|}
\hline Items & Needs \\
\hline $\begin{array}{c}\text { Team } \\
\text { Function }\end{array}$ & $\begin{array}{l}\text { Teams that make or do things, task teams } \\
\text { - Usually involves a supervisor and those who report to him } \\
\text { - Provide ideas for the process } \\
\text { - } \quad \text { Discuss and propose ways to improve the workplace arrangements, pro- } \\
\text { duction process and lines of communication } \\
\text { - Responsible for a clearly defined area of work, responsible for the whole } \\
\text { product or process; planning, performing, implementing and co- } \\
\text { ordinating improvements. } \\
\text { - Problem types are general and are specific for the team's defined area of } \\
\text { work. }\end{array}$ \\
\hline $\begin{array}{l}\text { Team } \\
\text { Perform- } \\
\text { ance }\end{array}$ & - Teams objectives are measurable and can be monitored. \\
\hline $\begin{array}{l}\text { Competi- } \\
\text { tion }\end{array}$ & $\begin{array}{l}\text { These teams generally compete against other teams within the organisation } \\
\text { or compete against constraints imposed on them by the tactical teams. These } \\
\text { constraints include daily throughput, number of defects, lost time, injuries, } \\
\text { and daily/weekly/monthly machine operating hours. }\end{array}$ \\
\hline $\begin{array}{l}\text { Team } \\
\text { Members } \\
\text { Roles }\end{array}$ & $\begin{array}{l}\text { Since these teams exist within a department the team composition can be } \\
\text { both functional and cross-functional depending on the task. } \\
\text { The team structure is generally formal with their being a team leader who is } \\
\text { responsible for scheduling, planning, co-ordinating and monitoring teams } \\
\text { tasks. }\end{array}$ \\
\hline $\begin{array}{l}\text { Relation- } \\
\text { ships }\end{array}$ & $\begin{array}{l}\text { Important relationship factors: } \\
\text { - These team memberships are generally within the division or department } \\
\text { - Teams are functional and consist of specialists } \\
\text { - Team lifecycle is long term } \\
\text { - Team size is dependent on the number of employees in the department or } \\
\text { division or business unit } \\
\text { - Teams may also use consultants or specialists }\end{array}$ \\
\hline $\begin{array}{l}\text { Team } \\
\text { Leader- } \\
\text { ship }\end{array}$ & $\begin{array}{l}\text { There are two types of team leadership styles that are characteristic of these } \\
\text { types of teams: } \\
\text { - Directive - teams at initiation, members unsure of tasks, leaders give } \\
\text { information and direction } \\
\text { - Delegating - teams competent and experienced, leaders respond to pro- } \\
\text { posals and suggestions from members }\end{array}$ \\
\hline $\begin{array}{l}\text { Team } \\
\text { Types }\end{array}$ & $\begin{array}{l}\text { - Quality circles } \\
\text { - Self-directed work teams } \\
\text { - Think tank teams } \\
\text { - Functional teams } \\
\text { - Working groups } \\
\text { - Cross-functional }\end{array}$ \\
\hline $\begin{array}{l}\text { Typical } \\
\text { Team } \\
\text { Structures }\end{array}$ & $\begin{array}{l}\text { - Problem resolution } \\
\text { - Tactical } \\
\text { - Creative } \\
\end{array}$ \\
\hline
\end{tabular}




\section{CONCLUDING REMARKS}

Available literature about the properties of teams has been analysed and represented in tabular and visual forms which can guide enterprise team selection processes and thereby realise an improved initial match between the competences of a team and the enterprise activities and tasks they are assigned. It is understood that subsequent to their implementation, teams will evolve their behaviours, processes and structures, i.e. as they better understand their tasks, interrelationships and the outputs they should generate (Syer, Connoly, 1996). In the context of process-oriented enterprise engineering the ability to reuse human factors knowledge afforded by the new tabulated reference model of teams offers means of starting team task development from a much-improved initial state.

\section{REFERENCES}

Anantharaman, V. Chong, L. Richardson, S. Tan, C. (1984), Human Resource Management: Concepts and Perspectives, Singapore, Singapore University Press.

Barker, J. R. (1993), Tightening the Iron Cage: Concertive Control in Self-Managing Teams, Administrative Science Quarterly, 38, pp. 388-407.

BS ISO 14258, (1998), Industrial automation systems - concepts and rules for enterprise models, British Standards Institute, Chiswick, London, UK.

Foster, S. F. Heling, G. W. J. Tideman, B. (1996), Teams in Intelligent Process Based Organisations. Lansa Publishing BV, Leiderdorp, The Netherlands.

Hardingham, A. (1994), Working in Teams. London, Institute of Personnel and Development, (P658.402/HAR).

Larson, C. E. LaFosto, F. M. J. (1989), Teamwork: What must go right/What can go wrong. Sage Publications, Newbury Park, California, USA.

Loughborough, http://msiri.lboro.ac.uk

Morris, A.J. Syamsudin, H. Fielding, J. P. Guenov, M. Payne, K. H. Deasley, P. J. Evans, S. Thorne, J. (2000), Macro- A tool to Support Distributed Multi-Disciplinary Design and Organisation, Cranfield University, Cranfield, UK.

Smith, K. and Berg, D. (1987), Paradoxes of Group Life. Jossey-Bass, London, UK.

Syer, J. Connolly, C. (1996), How Teamworking Works: The Dynamics of Effective Team Development. McGraw-Hill.

Tranfield, D. Parry, I. Wilson, S. Smith, S. and Foster, M. (1998), Teamworked Organisational Engineering: Getting the Most Out of Teamworking, Management Decision, 36(6), ISSN: 0025-1747. 